\title{
The Correlation between Information Technology Capability and Organizational Learning and Organizational Performance in PT "XXX" Pharma, Tbk., Pasuruan, East Java
}

\author{
Mashudi ${ }^{1}$, Luluk Fauziah ${ }^{2}$, Endang Larasati Setianingsih ${ }^{3}$, Ida Hayu Dwimawanti ${ }^{4}$, Ratih \\ Khoirul Aini ${ }^{5}$ \\ \{emashud@lecturer.undip.ac.id ${ }^{1}$ \} \\ Universitas Diponegoro, Indonesia ${ }^{1,2,3,4}$ \\ Universitas Muhammadiyah Sidoarjo, Indonesia ${ }^{5}$
}

\begin{abstract}
Departing from the close relationship of information technology capability and organizational learning to organizational performance in business organization management, this research aims to find out the effects of information technology capability on organizational learning, and information technology capability on organizational performance in PT. "XXX" Pharma, Tbk., Pasuruan, East Java. This research format is explanatory and survey, while the method employed is quantitative one. Data collection is conducted using questionnaire distributed to 44 respondents. The sampling technique used is purposive sampling one. Data processing is conducted using path analysis technique with International Business Machine (IBM) Predictive Analytic Software (PASW) software version 24 help. The result of research is as follows: Information technology capability affects organizational learning positively and significantly, information technology capability affects organizational performance positively and significantly, organizational learning affects organizational performance positively and significantly, and information technology capability does not affect organizational performance significantly through organizational learning.
\end{abstract}

Keywords: Information Technology Capability, Organizational Learning, Organizational Performance

\section{Introduction}

No business is without competitor, at both local and international levels. Thus, in improving its survival, business organization should have sophisticated strategy. This imperative is absolute, moreover when a business organization should face difficult time during global Corona-19 pandemic condition today. This condition may make the product not sold out because consumers encounter reduced income. This condition also likely makes the need for basic material unfulfilled because the supplier of basic material stops their operation. This condition requires the company to have varying information to support the management decision making in dealing with these difficult times. Venkatraman and Ramanujam [1] stated that in the presence of globalization and the increased international competition, the organization accelerates and improves its movement toward information technology. 
Increasingly tight global competition requires the company to response, to formulate strategy and to develop its capability, one of which is technology capability. Technology capability is an organizational or individual resource ability involving firm knowledge, skill, and experience to design, and to produce new innovative products, to improve competitive advantage, thereby achieving the product wanted by the company. Understanding technology capability can help company assess weaknesses and strengths to plan innovative technology strategy.

The capability of understanding information technology can be achieved when the company has people learning, and expanding knowledge and capacity continuously to create new and renewable products. This expansion of knowledge and capacity can be achieved if company has willingness and ability of investing in improving employees' competency. It can be done by means of funding education for employees in the study programs relevant to the hearth of company business at higher level. Employees' knowledge, capacity, and competency can be improved through conducting comparative study and continuous research in relevant fields. All of these, of course, need much investment.

These knowledge, capacity, and competency are strategic resources in company; the result of a series of research shows that company's capability can survive longer and develop over years due to not its physical resource size but to its ability of adapting quickly to the change occurring, so that the company management can move the company toward achieving its performance appropriately.

PT. "XXX" Pharma, Tbk has made innovation to provide scientific based-drugs. One of programs being applied intensively is Merck for Mothers, helping suppress maternal mortality rate, so that the company keeps conducting a variety of researches and new product developments. Core value applied includes diversity and teamwork. This company basing in New Jersey, USA wants to be the best one in science and attempts to give access to its products throughout world, and even it targets its products to be used by 80 percent of human population in the world, but the target has not been met today.

Considering the background and problem existing, the problem statements of research are as follows: 1) Does information technology capability affects organizational learning significantly?; Does information technology capability affects organizational performance significantly; 3) Does organizational learning capability affects organizational performance significantly?: and Does information technology capability affects organizational performance significantly through knowledge management capability?

\section{Literature Review}

\subsection{Theoretical Review}

\subsubsection{Information Technology Capability}

Williams and Sawyer [2] states that information technology is the one combining computation (computer) and communication carrying data, sound, and video. Alter [3] also states that information technology not only includes hardware and software used to process and to store information, but also includes communication technology to send information.

Martin [4] explains that information technology is not only limited to computer technology (hardware and software) used in processing and storing information, but also 
involves communication technology to send information. Information technology capability is the organizational skill enabling the function of information technology to give value to various company activities.

Some researches aim to understand how information technology resource provides value to organization [5], because most of these resources are considered as commodity available in the market. On the other hand, information technology skill has been identified as responsibility for the company's operational and financial performances [5].

Capability is characterized to be knowledge enabling organizations to do activities relevant to their survival and competitiveness [6]. Actually, information technology capability such as internal relationship and technical capacity [7][8], is an organizational skill enabling information technology to provide service effectively using overlapping resources [5][9].

The information technology capability is introduced by Ross et al. [8] defining information technology capability as company's ability of assembling, integrating, and applying information technology-based resource. Heijden [10] shows that the measurement of information technology capability involves the relations between information technology department and the rests in other business units.

Recalling the more importance of information in business environment, achieving competency and capability related to instrument and process used to manage information has gotten new urgency. This capability intended is information technology capability. Most studies analyzing information technology capability focus on information technology infrastructure and information technology skill necessary to utilize information technology potency. Considering this, the company's information technology capability can be defined as the company's ability of selecting, receiving, configuring, and applying information technology. In other words, information technology capability includes information technology infrastructure in the company, and supporting process and relevant knowledge.

\subsubsection{Learning Organization}

Learning organization concept is introduced for the first time by Peter Senge in 1990, and it still uses widely by both public and business organization until today to be the reference concerning what important the learning in an organization is. Senge reveals that there are five disciplines developed as the key to a successful organization development and change: 1) system thinking 2) personal mastery; 3) mental model; 4) building shared vision; and 5) team learning. These five disciplines are explained further below.

a) System Thinking

It is a way of thinking and a language to explain and to understand strength and relationship creating behavior in an organization's systems. This discipline helps see how to change the existing system in order to be more effective and to take action focusing more on the larger process.

b) Personal mastery

Personal mastery is a foundation of creativity and innovation in learning organization, including:

a. An individual's capacity to achieve their function or an individual's capability of creating life as he/she expects.

b. Any things related to a series of principles and practices.

c. Underlying competency and skill.

Personal mastery can be accomplished by means of:

a. Sharpening and deepening personal vision continuously. 
b. Developing capability and patience to see the reality objectively.

Some basic characteristics of personal mastery are:

a. Always be curious, having commitment continuously, seeing the reality more accurately.

b. Feeling bound to each other.

c. Learning sustainably but having never "arrived".

d. Having broad responsibility for his/her division.

e. Being self-confident actually

f. Being aware of self-ignorance and incapability.

The characteristics of an individual with high personal mastery are:

a. Clear personal vision.

b. Having high commitment.

c. Initiative and creative.

d. Having much self-confident.

e. Having much responsibility.

f. Always attempting to develop the self.

g. Capable of seeing reality objectively.

The importance of personal mastery in organization:

a. Supporting organization to develop.

b. Learning organization can occur when each of individuals in the organization does learning.

c. Achieving the organization's advantages.

d. Building shared vision.

c) Building Shared Vision

It is to build commitment in group, by developing the shared representation on the future wanting to be realized, and principle and practical instruction to achieve it. This vision provides focus, direction, and power to members of an organization. Learning is a way of fighting for achieving the vision.

d) Mental Model

Mental model is our mindset containing value and belief we uphold as the foundation or guidelines being to which we refer to in behaving or making decision. Those value and belief refer to our perspective (paradigm) on real world.

e) Team learning

It is a process combining and developing team's capacity in creating learning and achieving the result wanted by its members. The team involved should learn to give opportunity to many potential thoughts, thereby providing result better than one thought only. This team can transform conversation and collective thinking skill, so that each of group members can develop their intelligence and capability and thereby obtaining better result than the sum of individual competencies.

Marquardt [11] defines the characteristics of learning organization as follows:

a) Learning is conducted through organizational system entirely and organization as if has one brain.

b) All members of organization realize the importance of learning organization continuously to the successful organization today and in the future.

c) Learning is a process running continuously and conducted along with working activity.

d) Focusing on creativity and generative learning.

e) Considering thinking system as very important. 
f) Capable of accessing information source and data necessary for the successful organization.

g) Organizational climate encourages, accelerates, and rewards each individual to learn.

h) People are connected to each other in an innovative network as a community inside and outside organization.

i) The change is welcomed, and surprises and even failure are considered as learning opportunity.

j) Moving easily, quickly, and flexibly.

k) Each individual is encouraged to improve the quality continuously.

1) Activity builds on aspiration, reflection, and conceptualization.

m) Having core competence developed well as the reference to service and production.

n) Having adapting, reforming, and revitalizing capabilities as the answer to the changing environment.

\subsubsection{Organizational Performance}

Organizational performance is a theme often discussed in management discipline and a theme considered as interesting to academicians and practitioners. Although the importance of organizational performance concept has been recognized widely, it does not mean that organizational performance issue has been solved. Organizational performance has very broad scope and can be said as the most phenomenal and ever developing problem among academicians.

Organizational performance is a difficult concept in the term of its measurement and definition [12]. Organizational performance is the factor used to measure successful strategy implemented by the company or in other words, organizational performance is a concept to evaluate company's achievement or business activity performed.

In traditional perspective, organizational performance is often called financial performance in which budget, asset, operation, product, service, market, and human resource is very important to consider in affecting the organization entirely. Thus, financial benefit from organizational performance is often related to the organization's success [13]. However, the idea of performance includes fairly broad dimension.

A comprehensive approach to organizational performance consists of not only financial perspective but also all perspectives potential to assess the creation of value in organization. It means that to evaluate the performance of knowledge management program, non-financial indicators should also be taken into account, because knowledge management affects various aspects of performance. A comprehensive approach to this company performance takes financial profit, growth, and non-financial, creativity, customer satisfaction aspects into account [14].

Moeheriono [15] mentions that there are three types of performance in an organization:

a) Operation Performance

Operational performance relates to the effective use of all resources by company including capital, basic material, technology, and etc. It pertains to how the resource is used maximally to look for profit or to achieve the vision and mission of company.

b) Administrative Performance

Administrative performance relates to company's administrative performance, e.g., administrative structure governing the authority relation and the responsibility of those occupying the position, in addition it also relates to the performance of information flow mechanism among working units in the company. 
c) Strategic Performance

Strategic performance relates to company performance, evaluates the company's appropriate choice of environment and its adapting capability, particularly its strategy in performing its vision and mission.

Nfuka and Rusu [16] also argue that the measurement of organizational performance should be viewed from multidimensional perspectives. Viewed from one financial performance factor only, the result will be less perfect in representing the actual company performance condition [17]. The measurement of organizational performance, according to Brady and Cronin [18], can be viewed from two dimensions: market performance and financial performance. Market performance is intended to see the effectiveness of company in all of its market aspects. Meanwhile, financial performance is intended to see the extent to which the company's financial effectiveness, how the company yields profit and return to its investment.

Kaplan and Norton [19] argue that financial data is not the only objective to be achieved by the company. They add that the company uses quality measurement and performance evaluation to combine the company's better incentive and the output orientated to the company's long-term success. Kaplan and Norton have also developed practice to design performance indicator by combining the management incentive system and the organization's broader objective.

\subsection{Review on Previous Studies}

\subsubsection{Puryantini, Arfati and Tjahjadi. (2017). The Relationship among Knowledge Management, Organizational Learning and Organizational Performance}

The objective of research is to find out the relationship between knowledge management, organizational performance and organizational learning, and to find out whether or not organizational learning mediates the relationship between knowledge management and organizational performance.

The method of research is quantitative one and data is analyzed using LISREL and SEM path analyses. The result showed that: 1) Knowledge management affects organizational performance positively; 2) Knowledge management affects organizational learning positively; and 3) Organizational learning affects organizational performance positively. Organizational learning is a mediating variable for the relationship between knowledge management and organizational performance.

\subsubsection{Pebrianto and Djamhur. (2013). The Influence of Information Technology Capability, Organizational Learning and Knowledge Management Capability on Organizational Performance (A Study of Banking Branches Company in Southern Kalimantan Province)}

This research aims to examine and to explain the effects of information technology capability on organizational learning, information technology capability on knowledge management capability, information technology capability on organizational performance, organizational learning on knowledge management capability, organizational learning on organizational performance, and knowledge management capability on organizational performance. 
The methods used are qualitative, explanatory, and path analysis ones. The result shows information technology capability affects organizational learning significantly, information technology capability affects knowledge management capability significantly, information technology capability affects organizational performance significantly, organizational learning does not affect knowledge management capability significantly, organizational learning affects organizational performance significantly, and knowledge management capability affects organizational performance significantly.

\subsubsection{Sarand et al. (2015). Explaining the Relationships of Knowledge Management Processes with Organizational Performance through the Mediator Organizational Learning}

The objective of research is to find out the relationship between knowledge management, organizational performance and organizational learning variables in shabestar subsidiary of universitas azad Islam.

The method employed is qualitative with sem being the technique of analysis. The result shows: there is a positive significant relationship between knowledge management on the one hand, and organizational learning and organizational performance on the other hand. In addition, organizational learning variable is found to have positive significant relationship with organizational performance. The finding of research confirms the significant effect of organizational learning as mediator in the relationship between knowledge management and organizational performance.

\subsubsection{Nafei. (2015). The Mediating Effects of Organizational Learning on the Relationship between Knowledge Management and Organizational Performance: An Applied Study on the Egyptian Commercial Banks}

The objective of research is to find out and to analyze the important mediating role of organizational learning in the relationship between knowledge management and organizational performance. It is also intended to explore the important role of knowledge management in achieving superior organizational performance. This research analyzes how knowledge management creates organizational learning and how organizational learning contributes to organizational performance.

The method used in this research is quantitative, while data analysis is conducted using regression technique. The result shows: knowledge management affects organizational learning, organizational learning affects organizational performance, knowledge management affects organizational performance, and knowledge management affects organizational performance through organizational learning.

\section{Method}

The variables in this research are information technology capability, organizational learning, and organizational performance. The relationship between variables can be seen in diagram 1 . 


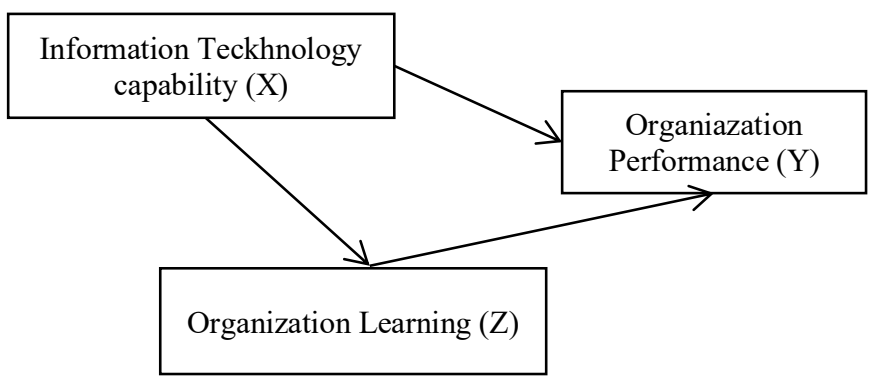

Diagram 1. The Relationship Between Variables.

This research employs quantitative method with explanatory and survey formats. This research takes place in PT. "XXX" Pharma, Tbk., Pasuruan, East Java. The population of research consists of 286 employees. The sample consists of 44 employees, taken using purposive random sampling technique. The employees selected to be the sample are those with position at least supervisor and having subordinates. Data collection is conducted by distributing questionnaire. To enrich the finding of questionnaire, interview and documentation are used.

The questionnaire in this research is tested for its validity and reliability. Before being processed further, the data is tested using classical assumption test including normality, linearity, heteroscedasticity, and multi-collinearity tests. Data analysis is conducted using path analysis technique with International Business Machine (IBM) Predictive Analytic Software (PASW) software version 24 help.

\section{Result and Discussion}

The result of classical assumption test is as follows: The result of normality test using Kolmogorov Smirnov indicates significance value (Sig.) of information technology capability $(0,060)$, organizational learning $(0,200)$, and organizational performance variables $(0,118)$ more than significance level $(0,05)$. Therefore, all variables are distributed normally.

The result of linearity test indicates the significance value of deviation from linearity for the two variables $(0.474)$ more than significance level $(0.05)$. Therefore, the correlation between information technology capability and organizational performance is linear. The significance value of deviation from linearity for the two variables $(0.474)$ more than significance level (0.05). Therefore, the correlation between organizational learning and organizational performance is linear.

In this research, heteroscedasticity test is conducted using scatterplot graphic the result of which is shown by the points of data spreading evenly above and below zero (null) line, not assembling in one place, and not creating certain pattern, thereby it can be said that there is no heteroscedasticity problem.

The result of multi-collinearity test shows that Variance Inflation Factor (VIF) value of information technology capability variable is 3.249 and that of organizational learning variable is 3.143 less than 10 . Therefore, those variables do not encounter multi-collinearity problem. 


\subsection{Information Technology Capability (X) affects Organizational Learning (Z)}

Table 1 shows that path coefficient of variables $\mathrm{X}_{1}$ to $\mathrm{Z}$ is 0.324 with tstatistic value of 2.151 and significance value of 2.018 for significance level of 0.05 two side test, sample size $(n)=44$, and degree of freedom (df) $n-2=42$. Because, tstatistic value (2.151) is more than table (2.018) and significance value (0.037) less than $0.05, \mathrm{H}_{0}$ is not supported and $\mathrm{H}_{1}$ stating that Information Technology Capability affects Organizational Learning positively and significantly is supported, meaning that in Information Technology Capability affects Organizational Learning in PT "XXX" Pharma. Thus, the better the Information Technology Capability, the better is the Organizational Learning.

The result of hypothesis testing shows that Information Technology Capability affects Organizational Learning significantly in PT "XX" Pharma. It can be seen from tstatistic value (2.151) more than table (2.018) and significance value (0.037) less than significance level (0.05). In addition, path coefficient of 0.324 is obtained, meaning that each one-point increase in Information Technology Capability will increase Organizational Learning by 0.324 points.

Table 1. Coefficients

\begin{tabular}{|c|c|c|c|c|c|c|}
\hline \multicolumn{7}{|c|}{ Coefficients $^{\mathrm{a}}$} \\
\hline & \multirow[t]{2}{*}{ Model } & \multicolumn{2}{|c|}{$\begin{array}{c}\text { Unstandardized } \\
\text { Coefficients }\end{array}$} & \multirow{3}{*}{$\begin{array}{c}\begin{array}{c}\text { Standardized } \\
\text { Coefficients }\end{array} \\
\text { Beta } \\
\end{array}$} & \multirow[b]{3}{*}{3.939} & \multirow[t]{2}{*}{ Sig. } \\
\hline & & $\mathrm{B}$ & Std. Error & & & \\
\hline \multirow[b]{2}{*}{1} & (Constant) & 20.173 & 5.122 & & & .000 \\
\hline & $\begin{array}{c}\text { Information Technology } \\
\text { Capability (X) }\end{array}$ & .330 & .153 & .324 & 2.151 & .037 \\
\hline & endent Variable: Organ & onal Le & $\operatorname{ng}(Z)$ & & & \\
\hline
\end{tabular}

The result of research is in line with Pebrianto's (2013) study finding that Information Technology Capability affects Organizational Learning significantly.

Information technology has a large potency to support organizational learning through representing, storing, capturing, and taking structured data, diagram, model, text and image in electronic database [20][21]. The utilization of information technology, according to Robey et al. [22], on the one hand supports the learning process and improves the organizational learning capacity, while organizational learning facilitates the adoption and the implementation of new technology change in organization on the other hand.

Thus, this research shows evidently that Information Technology Capability affects Organizational Learning significantly.

\subsection{Information Technology Capability (X) affects Organizational Performance} (Y)

Table 2 shows that path coefficient of variables $\mathrm{X}$ to $\mathrm{Y}$ is to $\mathrm{Z}$ is 0.282 with $\mathrm{t}_{\text {statistic }}$ value of 2.145 and significance value of 0.038 . From $t$ distribution table, it can be seen table value of 2.018 for significance level of 0.05 two side test, sample size $(n)=44$, and degree of freedom (df) $\mathrm{n}-2=42$. Because, $\mathrm{t}_{\text {statistic }}$ value (2.145) is more than table (2.018) and significance value (0.038) less than $0.05, \mathrm{H}_{0}$ is not supported and $\mathrm{H}_{1}$ stating that Organizational Learning affects 
Organizational Performance significantly is supported, meaning that Information Technology Capability affects Organizational Learning significantly in PT "XXX" Pharma. Thus, the better the Information Technology Capability, the better is the Organizational Performance.

Table 2. Coefficients

\begin{tabular}{|c|c|c|c|c|c|c|}
\hline \multicolumn{7}{|c|}{ Coefficients $^{\mathbf{a}}$} \\
\hline & \multirow{2}{*}{ Model } & \multicolumn{2}{|c|}{$\begin{array}{c}\text { Unstandardized } \\
\text { Coefficients } \\
\end{array}$} & \multirow{2}{*}{$\begin{array}{c}\begin{array}{c}\text { Standardized } \\
\text { Coefficients }\end{array} \\
\text { Beta }\end{array}$} & \multirow{2}{*}{$\mathrm{t}$} & \multirow{2}{*}{ Sig. } \\
\hline & & $\mathrm{B}$ & $\begin{array}{l}\text { Std. } \\
\text { Error }\end{array}$ & & & \\
\hline \multirow{3}{*}{1} & (Constant) & 5.457 & 3.595 & & 1.518 & .137 \\
\hline & $\begin{array}{c}\text { Information Technology } \\
\text { Capability (X) }\end{array}$ & .207 & .097 & .282 & 2.145 & .038 \\
\hline & $\begin{array}{c}\text { Organizational Learning } \\
(\mathrm{Z})\end{array}$ & .257 & .093 & .356 & 2.754 & .009 \\
\hline
\end{tabular}

The result of hypothesis testing shows Information Technology Capability affects Organizational Performance significantly in PT "XXX". It can be seen from $\mathrm{t}_{\text {statistic value }}$ (2.145) more than table (2.018) and significance value (0.038) less than (0.05). In addition, path coefficient of 0.282 is obtained, meaning that each one-point increase in Information Technology Capability will increase Performance by 0.282 .

The result of research is in line with Pebrianto's (2013) study indicating that Information Technology Capability affects Organizational Performance.

Information technology capability used for production and operation can improve organizational performance that should plan, monitor, and control supply, facility, and product flow and service. Many production systems and productions can deal with operation and maintain production facilities efficiently, set up the objective, acquire, store, and distribute production material and schedule instruments, facilities, materials, and workers needed to satisfy the order [23].

Through developing information technology capability, the company can create competitive advantage, and essentially can improve organizational performance. Information technology capability, in its relation to other organizational capability, can exert positive synergic effect much more difficult to imitate or to replace by competitor [24][25].

Thus, this research evidently shows that Information Technology Capability affects Organizational Performance significantly.

\subsection{Organizational Learning (Z) Affects Organizational Performance (Y)}

a) Table 2 shows that path coefficient of variables Z to $Y$ is 0.356 with $t_{\text {statistic }}$ of 2.754 and significance value (Sig.) of 0.009. Because $t_{\text {statistic }}(2.754)$ more than $t_{\text {table }}(2.018)$ and significance level (0.009) less than $0.05, \mathrm{H}_{0}$ is not supported and $\mathrm{H}_{1}$ is supported, meaning that Organizational Learning affects Organizational Performance significantly in PT "XXX" Pharma. Thus, the better the Organizational Learning, the better is the Organizational Performance.

b) The result of hypothesis testing shows that Organizational Learning affects Organizational Performance significantly in PT "XXX". It can be seen from tstatistic value (2.754) more than $t_{\text {table }}(2.018)$ and significance value (0.009) less than significance level 
(0.05). In addition, path coefficient of 0.356 is obtained, meaning that each 1 (one) point increase in Organizational Learning will increase Organizational Performance by 0.356 point. In fact, the effect of Organizational Learning (0.356) is more than that of Knowledge Management Capability (0.317) and Information Technology Capability (0.282) on Organizational Performance in PT "XXX" Pharma.

This result is in line with Pebrianto's (2013), Sarandet et al.’s (2015), Nafei's (2014) studies finding that Organizational Learning affects Organizational Performance significantly.

Theriou and Chatzoglou [26] states that knowledge management and organizational learning play unique role to themselves in creating organizational capability, thereby resulting in superior performance. Indentation indicates that the company applies the effect of organizational learning performance.

Organizational learning capability will affect organizational learning process. The organization with good learning ability, whether at individual, group, or organizational level, will be able to perform good learning process as well. The good learning process will result in good working output in the organization. It can be said that organizational performance can be considered as a part of organizational learning's role.

Thus, this research shows evidently that Organizational Learning affects Organizational Performance significantly.

\subsection{The effect of Information Technology Capability (X) on Organizational Performance (Y) through Organizational Learning (Z)}

To examine the significance of the indirect effect of exogenous variable on endogenous variable, $t_{\text {statistic }}$ value should calculated in the formula below:

$$
\mathrm{t}_{\mathrm{be}}=\frac{\mathrm{be}}{\text { Sbe }}=\frac{0,330 \times 0,257}{0,055}=1,542
$$

Meanwhile, the effect of Information Technology Capability on Organizational Performance through Organizational Learning $(X \rightarrow Z \rightarrow Y)=(0.324 \times 0.356)=0.115$.

Thus, it can be seen that the direct effect of Information Technology Capability on Organizational Performance through Organizational Learning has mediating coefficient of 0.115 with $t_{\text {statistic }}$ value of 1.542 . Because $t_{\text {statistic }}$ value $(1.542)$ less than $t_{\text {table }}(2.018), \mathrm{H}_{0}$ is supported, meaning that Information Technology Capability does not affect Organizational Performance significantly through Organizational Learning in PT "XXX" Pharma.

The result of hypothesis testing shows that Information Technology Capability does not affect Organizational Performance significantly through Organizational Learning in PT "XXX" Pharma. It can be seen from tstatistic value (1.542) less than table (2.018). In addition, the indirect effect of Information Technology Capability on Organizational Performance through Organizational Learning $\left(\mathrm{X}_{1} \rightarrow \mathrm{Z} \rightarrow \mathrm{Y}\right)$ has value of 0.115 less than the effect of Information Technology Capability on Organizational Performance $\left(\mathrm{X}_{1} \rightarrow \mathrm{Y}\right), 0.282$.

This finding is different from Sarandet et al. (2015), Mubeen and Ashraf's (2016), and studies finding that Organizational Learning is a moderating variable for the correlation between Knowledge Management and Organizational Performance. This research cannot prove that Information Technology Capability affects Organizational Performance significantly through Organizational Learning. 


\section{Conclusion}

The effect of information technology capability on organizational learning has positive value; it means that the higher the value of information technology capability, the higher is the organizational learning. Employees knowledge on information technology technically, how far information technology supports the company's operation effectively and efficiently, and how far infrastructure supports information technology activities in the company play very strategic roles in knowledge process such as inventing, storing or retrieving, transfer, and applying knowledge.

The effect of information technology capability on organizational performance has positive value, meaning that the higher the value of information technology capability, the higher is the value of organizational performance. The higher information technology capability the employees have plays fairly important role in organizational performance.

Organizational Learning affects Organizational Performance significantly, as indicated with path coefficient of 0.356 , tstatistic value of 2.754 and significance value of 0.009 . The positive value indicates that the higher the organizational learning, the higher is the effect of its on organizational performance.

Information Technology Capability does not affect Organizational Performance significantly through Organizational Learning, as indicated with mediating coefficient of 0.115 and $t_{\text {statistic }}$ value of 1.542. It indicates that the change occurring in information technology capability affects organizational performance insignificantly through organizational learning.

\section{References}

[1] N. Venkatraman and V. Ramanujam, "Measurement of business economic performance: an examination of method convergence," J. Manage., vol. 13, no. 1, pp. 109-122, 1987.

[2] B. K. Williams and S. C. Sawyer, Using information technology: A practical introduction to computers \& communications. 2007.

[3] S. Alter, "Information Systems: A Management Perspective, 2nd ed.," in Menlo Park, CA: The Benjamin/Cummings, 1996.

[4] S. Gregor, M. Martin, W. Fernandez, S. Stern, and M. Vitale, "The transformational dimension in the realization of business value from information technology," J. Strateg. Inf. Syst., vol. 15, no. 3, pp. 249-270, 2006.

[5] A. S. Bharadwaj, "A resource-based perspective on information technology capability and firm performance: an empirical investigation," MIS Q., pp. 169-196, 2000.

[6] G. Dosi, R. R. Nelson, and S. G. Winter, The nature and dynamics of organizational capabilities. Oxford university press, 2000.

[7] J. B. Barney and D. N. Clark, Resource-based theory: Creating and sustaining competitive advantage. Oxford University Press on Demand, 2007.

[8] J. W. Ross, C. M. Beath, and D. L. Goodhue, "Develop long-term competitiveness through IT assets," Sloan Manage. Rev., vol. 38, no. 1, pp. 31-42, 1996.

[9] T. Ravichandran, C. Lertwongsatien, and C. Lertwongsatien, "Effect of information systems resources and capabilities on firm performance: A resource-based perspective," J. Manag. Inf. Syst., vol. 21, no. 4, pp. 237-276, 2005.

[10] H. Van der Heijden, "User acceptance of hedonic information systems," MIS Q., pp. 695-704, 2004.

[11] M. J. Marquardt, Building the learning organization: Mastering the 5 elements for corporate learning. Nicholas brealey publishing, 2002.

[12] B. W. Keats and M. A. Hitt, "A causal model of linkages among environmental dimensions, 
macro organizational characteristics, and performance," Acad. Manag. J., vol. 31, no. 3, pp. 570-598, 1988.

[13] E. Turban and L. Volonino, Information Technology for management. John Wiley \& Sons Asia, 2010.

[14] C. López-Nicolás and Á. L. Meroño-Cerdán, "Strategic knowledge management, innovation and performance," Int. J. Inf. Manage., vol. 31, no. 6, pp. 502-509, 2011.

[15] P. Moeheriono and D. M. Si, "Competency based performance measurement," Jakarta, Indones. Rajagrafindo Persada, 2014.

[16] E. N. Nfuka and L. Rusu, "The effect of critical success factors on IT governance performance," Ind. Manag. Data Syst., 2011.

[17] R. A. Khan, "Sustainable competitive Advantage through knowledge management," Int. J. Adv. Res. Comput. Technol., vol. 3, no. 4, pp. 1079-1082, 2014.

[18] M. K. Brady and J. J. Cronin Jr, "Some new thoughts on conceptualizing perceived service quality: a hierarchical approach," J. Mark., vol. 65, no. 3, pp. 34-49, 2001.

[19] R. S. Kaplan and D. P. Norton, "Strategic learning \& the balanced scorecard," Strateg. Leadersh., 1996.

[20] V. Anand, C. C. Manz, and W. H. Glick, "An organizational memory approach to information management," Acad. Manag. Rev., vol. 23, no. 4, pp. 796-809, 1998.

[21] W. J. Devenport, M. C. Rife, S. I. Liapis, and G. J. Follin, "The structure and development of a wing-tip vortex," J. Fluid Mech., vol. 312, pp. 67-106, 1996.

[22] D. Robey, M.-C. Boudreau, and G. M. Rose, "Information technology and organizational learning: a review and assessment of research," Accounting, Manag. Inf. Technol., vol. 10, no. 2, pp. $125-155,2000$.

[23] K. C. Laudon and J. P. Laudon, "Management Information.” Systems, 2006.

[24] E. Alvarez-Suescun, "Testing resource-based propositions about IS sourcing decisions," Ind. Manag. Data Syst., 2007.

[25] T. Liang, J. You, and C. Liu, "A resource-based perspective on information technology and firm performance: a meta analysis," Ind. Manag. Data Syst., 2010.

[26] G. N. Theriou and P. D. Chatzoglou, "Enhancing performance through best HRM practices, organizational learning and knowledge management," Eur. Bus. Rev., 2008. 